\title{
Inez BILIŃSKA
}

Akademia Wychowania Fizycznego im. Eugeniusza Piaseckiego w Poznaniu

\section{Szymon OsSOWSKI}

Uniwersytet im. Adama Mickiewicza w Poznaniu

\section{Sytuacja społeczno-polityczna osób niepelnosprawnych ${ }^{1}$ w III RP}

soby niepełnosprawne stanowią w Polsce znaczny odsetek obywate-
li, a więc - o czym nadal często się zapomina - również wyborców. Cały czas stosunek do osób z różnego rodzaju dysfunkcjami w przestrzeni publicznej wymaga wielu zmian. Dotyczy to nie tyle prawa (choć po części również), co przede wszystkim postaw znacznej części Polaków. Z badania „Postawy wobec osób niepełnosprawnych” zrealizowanego przez Centrum Badania Opinii Społecznej w 2007 roku wynika, że „W ciaggu ostatnich siedmiu lat nie nastąpiły znaczące różnice w kontaktach ogółu polskiego społeczeństwa z osobami niepełnosprawnymi ani w ocenie stosunku Polaków do nich. Tak jak w roku 2000 większość an-

1 Światowa Organizacja Zdrowia (WHO) niepełnosprawność określa jako wszelkie ograniczenie lub brak (wynikający z uszkodzenia) możliwości wykonywania pewnych czynności w sposób lub w zakresie uznanym za normalny dla ludzi. Należy pamiętać, że osoby niepełnosprawne posiadają orzeczenie o niepełnosprawności. Ponadto cześć chorób przewlekłych może prowadzić do niepełnosprawności, ale np. choroby zakaźne nie prowadzą do niepełnosprawności. Natomiast, co trzeba z całą mocą podkreślić, niepełnoprawność nie jest chorobą. W końcu amputacji czy zatrzymania rozwoju intelektualnego nie leczy się tabletkami! Pojęciem pokrewnym do niepełnosprawności jest upośledzenie, które oznacza poszkodowanie wynikające z uszkodzenia lub niepełnosprawności, które ogranicza lub uniemożliwia danej osobie pełnienie ról, jakie uznaje się za normalne, uwzględniając wiek, płeć, czynniki społeczne i kulturowe (WHO). Z kolei niepełnosprawność intelektualna oznacza istotne obniżenie ogólnego poziomu funkcjonowania intelektualnego oraz trudności w zachowaniu przystosowawczym, występujące przed 18 rokiem życia. Znane są przypadki nieuleczalne. Przedstawione powyżej różnice terminologiczne są istotne, gdyż terminy te są bardzo często zamiennie i nie zawsze trafnie stosowane, czego przykładem mogą być choćby pewne zapisy omawianego w niniejszej pracy kodeksu wyborczego czy też przywołanych na wstępie wyników badań opinii publicznej przeprowadzonych przez Centrum Badania Opinii Społecznej. Por. www.who.un.org.pl. 
kietowanych uważa, że osoby niepełnosprawne powinny być otoczone opieką przede wszystkim ze strony rodziny, ale powinny również otrzymywać wsparcie ze strony pracowników służby zdrowia i pomocy społecznej. Obecnie nieco mniej osób niż przed siedmiu laty deklaruje chęć niesienia pomocy osobie niepełnosprawnej mieszkającej w sąsiedztwie. Podobnie jak w poprzednim badaniu, gotowość Polaków do pomagania jest uzależniona od rodzaju niepełnosprawności. Zmieniły się opinie i postawy respondentów wobec zatrudniania ludzi o niepełnej sprawności. Coraz więcej ankietowanych jest przekonanych, że osoby niepełnosprawne powinny mieć prawo do zatrudnienia oraz pracować na otwartym rynku pracy wśród sprawnych pracowników. Ponadto w stosunku do poprzedniego badania zmniejszyła się nieco grupa, która opowiada się za tym, aby niepełnosprawni obok wynagrodzenia za swoją pracę otrzymywali rentę"2.

Prawie połowa ankietowanych (45\%) pozytywnie oceniła stosunek Polaków do osób niepełnosprawnych, niemal tyle samo badanych (48\%) było przeciwnego zdania. Zdecydowana większość Polaków (76\%) opowiadała się za zatrudnianiem osób niepełnosprawnych razem ze zdrowymi pracownikami, natomiast co szósty (17\%) popierał segregacyjny model zatrudnienia. Dwie trzecie ankietowanych (65\%) deklarowało gotowość udzielania bezinteresownej pomocy sąsiedzkiej osobie niepełnosprawnej. Zaledwie $6 \%$ badanych twierdziło, że już uczestniczy w takiej pomocy, a co piąty (20\%) nie chciałby wziąć udziału w tego rodzaju inicjatywie. Deklarowana gotowość niesienia pomocy była uzależniona od rodzaju niepełnosprawności. Jak pokazują wyniki badania najrzadziej Polacy chcieliby pomagać osobom z chorobami psychicznymi ${ }^{3}$. Z badania wysunięto więc ogólny wniosek, że ,zasadnicze zmiany w kontaktach osób pełnosprawnych z niepełnosprawnymi miały miejsce w latach

2 Centrum Badania Opinii Społecznej, Postawy wobec osób niepetnosprawnych, Komunikat z badań BS/169/2007, listopad 2007, http:/www.cbos.pl/SPISKOM.POL/2007/K_169_07.PDF (dostęp 23.11.2012.).

3 Pojęcie choroba psychiczna budzi wiele kontrowersji. Głównym źródłem kontrowersji jest sprzeczność pomiędzy rezygnacją w psychiatrii z pojęcia choroby psychicznej a utrzymywaniem tego terminu w niektórych przepisach prawnych. Zgodnie z art. 3 ustawy z dnia 19 sierpnia 1994 roku o ochronie zdrowia psychicznego (Dz. U. 1994, Nr 111, poz. 535 ze zm.), zaburzenia psychiczne dzielimy w Polsce na: choroby psychiczne, tj. stany, w których obecne są zaburzenia psychotyczne, upośledzenia umysłowe, inne zakłócenia czynności psychicznych. Aktualnie odchodzi się jednak od stosowania tego terminu. 
dziewięćdziesiątych i wiązały się ze zmianą polityki społecznej, odejściem od tworzenia instytucji zapewniających osobom niepełnosprawnym opiekę i rehabilitację (ale jednocześnie izolację), upowszechnianiem działań prointegracyjnych, zachęcających osoby niepełnosprawne do pełnej partycypacji we wszystkich formach życia społecznego, a ogół społeczeństwa do otwarcia się na takie osoby" "4.

Nie przełożyło się to jednak w sposób widoczny dotychczas na aktywność obywatelską tych osób, w tym na ich udział w wyborach (czynny i bierny). Można wręcz stwierdzić, że to właśnie niepełnosprawność, a nie brak zainteresowania polityką, była dla osób z różnego rodzaju dysfunkcjami głównym powodem absencji wyborczej. Potwierdzają to przynajmniej w części wyniki badania „Przyczyny absencji w wyborach parlamentarnych i prezydenckich" zrealizowanego w 2005 roku przez Centrum Badania Opinii Społecznej ${ }^{5}$. Jako przyczynę chorobę przewlekłą, niepełnosprawność, trudności z poruszaniem się podało $12 \%$ ankietowanych. Był to główny motyw absencji uzasadnianej powodami obiektywnymi i niezależnymi od respondentów. Z podobnych przyczyn wymienić należy $2 \%$ odpowiedzi zwracających uwagę na kwestię wieku (,jestem za stary”), jak również 2\% osób, które nieobecność usprawiedliwiało głównie opieką nad osobą niepełnosprawną i dzieckiem. Wyniki pokazały, że obiektywne przyczyny absencji mają większe znaczenie, niż można było oczekiwać na podstawie wcześniejszych danych. „Nawet jeśli weźmiemy poprawkę na powyborczą potrzebę usprawiedliwienia własnej nieobecności, to widać dość wyraźnie, że jest wiele obiektywnych przyczyn nieobecności na wyborach, dla których warto dyskutować o zmianach w sposobie ich organizowania w Polsce, tak, by umożliwić udział w głosowaniu wszystkim tym, którzy chcą to zrobić, ale nie mogą. Około jednej piątej niegłosujących nie uczestniczyło w wyborach ze względu na stan zdrowia lub przyczyny społeczne, takie jak konieczność opieki nad chorym lub dzieckiem. Państwo ma obowiązek zapewnienia możliwości głosowania wszystkim obywatelom i utrzymywanie mocnych i w sumie dość archaicznych ograniczeń, jeśli wziąć pod uwa-

4 Centrum Badania Opinii Społecznej, Postawy wobec osób niepetnosprawnych, op. cit.

5 Centrum Badania Opinii Społecznej, Przyczyny absencji $w$ wyborach parlamentarnych $i$ prezydenckich, Komunikat z badań BS189/200, grudzień 2005, http://www.cbos.pl/SPISKOM.POL/2005/K_189_05.PDF (dostęp 23.11.2012.). 
gę systemy wyborcze w krajach europejskich, w możliwościach udziału w wyborach wydaje się co najmniej godne dyskusji"

Jednym z przykładów mogących się w niedalekiej przyszłości realnie przyczynić do faktycznego upodmiotowienia osób niepełnosprawnych jako obywateli - wyborców, są zapisy ustawy z dnia 5 stycznia 2011 roku Kodeks wyborczy (Dz. U. 2011, Nr 21, poz. 112 ze zm.). Artykuł 5 ustawy definiuje nawet pojęcie wyborcy niepełnosprawnego, którym jest wyborca o ograniczonej sprawności fizycznej, psychicznej, umysłowej lub w zakresie zmysłów, która utrudnia mu wzięcie udziału w wyborach. Kodeks zawiera cały szereg udogodnień. Zgodnie z art. 16 wójt podaje, w formie obwieszczenia, do wiadomości wyborców między innymi informację o lokalach obwodowych komisji wyborczych dostosowanych do potrzeb wyborców niepełnosprawnych. Zgodnie z art. 27 wyborca niepełnosprawny, na jego pisemny wniosek wniesiony do urzędu gminy najpóźniej w 14 dniu przed dniem wyborów, jest dopisywany do spisu wyborców w wybranym przez siebie obwodzie głosowania spośród obwodów głosowania, w których znajdują się lokale, na obszarze gminy właściwej ze względu na miejsce jego stałego zamieszkania. Kodeks zawiera osobny rozdział 5a ,przekazywanie informacji o wyborach wyborcom niepełnosprawnym", zgodnie z zapisami którego wyborca niepełnosprawny wpisany do rejestru wyborców w danej gminie ma prawo do uzyskiwania informacji między innymi o komitetach wyborczych biorących udział w wyborach oraz zarejestrowanych kandydatach i listach kandydatów, jak również o warunkach i formach głosowania. Te i inne zawarte $\mathrm{w}$ art. 37a informacje przekazuje wójt lub upoważniony przez niego pracownik urzędu gminy w godzinach pracy urzędu, $\mathrm{w}$ tym telefonicznie, lub $\mathrm{w}$ drukowanych materiałach informacyjnych przesyłanych na wniosek wyborcy niepełnosprawnego, w tym w formie elektronicznej. Zgodnie z art. 37b Państwowa Komisja Wyborcza sporządza w alfabecie Braille'a materiał informacyjny o uprawnieniach przysługujących wyborcom niepełnosprawnym na podstawie kodeksu i przekazuje go zainteresowanym na żądanie. Według art. 37c obwieszczenia wyborcze umieszczane w lokalu wyborczym, jak i poza nim oraz wyniki głosowania w obwodach głosowania i okręgach wyborczych powinny być zamieszczane w miejscach łatwo dostępnych dla osób niepełnosprawnych o ograniczonej sprawności ruchowej. Co istotne i zawarte

6 Ibidem. 
w art. 40a, wyborca niepełnosprawny może głosować przy użyciu nakładek na karty do głosowania sporządzonych w alfabecie Braille'a ${ }^{7}$, a zgodnie $\mathrm{z}$ art. 53 wyborcy niepełnosprawnemu, na jego prośbę, może pomagać inna osoba, z wyłączeniem członków komisji wyborczych i mężów zaufania.

Niezwykle istotny jest również rozdział 7 o głosowaniu przez pełnomocnika. Zgodnie z art. 54 wyborca niepełnosprawny o znacznym lub umiarkowanym stopniu niepełnosprawności w rozumieniu ustawy $\mathrm{z}$ dnia 27 sierpnia 1997 r. o rehabilitacji zawodowej i społecznej oraz zatrudnianiu osób niepełnosprawnych (Dz. U. 2011, Nr 127, poz. 721) może udzielić pełnomocnictwa do głosowania w jego imieniu w wyborach, zwanego dalej ,pełnomocnictwem do głosowania”. Ponadto zapis ten stosuje się również do wyborcy, który najpóźniej w dniu głosowania kończy 75 lat. Kolejnym bardzo dobrym rozwiązaniem jest zapisane w rozdziale 7a głosowanie korespondencyjne przez wyborców niepełnosprawnych. Art. 61a stwierdza, że wyborca niepełnosprawny o znacznym lub umiarkowanym stopniu niepełnosprawności w rozumieniu ustawy z dnia 27 sierpnia 1997 r. o rehabilitacji zawodowej i społecznej oraz zatrudnianiu osób niepełnosprawnych może głosować korespondencyjnie. Zgodnie $\mathrm{z}$ art. $61 \mathrm{~b}$ dla celów głosowania korespondencyjnego wójt wyznacza co najmniej jedną obwodową komisję wyborczą na terenie gminy. Art. 61c stwierdza, że zamiar głosowania korespondencyjnego powinien być zgłoszony przez wyborcę niepełnosprawnego wójtowi do 21 dnia przed dniem wyborów. Zgodnie z zapisami art. 61f wyborca niepełnosprawny, który zgłosił zamiar głosowania korespondencyjnego, otrzymuje z urzędu gminy pakiet wyborczy, nie później niż 7 dni przed dniem wyborów. Pakiet wyborczy, jest doręczany co do zasady do wyborcy przez upoważnionego pracownika urzędu gminy. Art. 61h stwierdza, że wyborca niepełnosprawny głosujący korespondencyjnie po wypełnieniu karty do głosowania wkłada ją do koperty na kartę do głosowania,

${ }^{7}$ Ustawodawca miał na myśli raczej osoby niewidome lub ociemniałe. Do osób niewidomych zaliczamy dzieci i dorosłych, którzy nie widzą od urodzenia, albo od wczesnego dzieciństwa tak, że nie pamiętają żadnych wrażeń wzrokowych. Do ociemniałych zalicza się wszystkich, którzy widzieli, lecz potem utracili wzrok. Niewidomi są oczywiście zaliczani do osób niepełnosprawnych, ale nie każdy niepełnosprawny jest niewidomym. Nakładek pisanych Braille'm na karty wyborcze osoba po amputacji, czy człowiek którego rozwój umysłu zatrzymał się na poziomie rocznego dziecka, nie potrzebuje. 
którą zakleja, a następnie kopertę tę wkłada do koperty zwrotnej łącznie z podpisanym oświadczeniem, i przesyła ją do właściwej obwodowej komisji wyborczej. Koperty zwrotne doręczane są do właściwych obwodowych komisji wyborczych w godzinach głosowania. Rozwiązania te przynajmniej teoretycznie powinny wpłynąć na zwiększenie frekwencji wśród osób z różnego rodzaju dysfunkcjami.

Służą temu również kampanie społeczne (ciaggle będące jednak rzadkością) jak na przykład będąca zresztą w pewnym sensie efektem zapisów wprowadzonych do kodeksu wyborczego ${ }^{8}$ kampania „Idziemy na wybory!”, twarzą której był Janusz Świtaj, od 18. roku życia sparaliżowany czterokończynowo (mówiąc potocznie od głowy w dół) po wypadku motocyklowym. W 2007 r. Świtaj pomimo swojej niepełnosprawności wziął udział w wyborach parlamentarnych. Razem z łóżkiem został wniesiony do ambulansu, a następnie przewieziony do lokalu wyborczego, gdzie mógł samodzielnie oddać głos. W ramach kampanii zrealizowano: po cztery spoty telewizyjne i radiowe, cztery reklamy prasowe i internetowe oraz filmy instruktażowe - konsekwentnie informujące o nowych możliwościach głosowania i datach istotnych przy wyborze każdego sposobu głosowania. Świtaj przekonywał, że „Swoim uczestnictwem w wyborach dałem przykład obywatelskiej postawy wszystkim osobom z niepełnosprawnością, które często są dotknięte kalectwem w mniejszym stopniu ode mnie, a i tak nie głosują. Teraz już nikt nie może mieć żadnej wymówki! Ułatwienia prawne dają nam szereg możliwości, aby oddać głos, dlatego zachęcam wszystkie osoby z niepełnosprawnością do wzięcia udziału w wyborach"".

Zgodnie z ustawą o rehabilitacji zawodowej i społecznej oraz zatrudnianiu osób niepełnosprawnych (Dz. U. 2088, Nr 14, poz. 92), niepełnosprawnymi są osoby, których stan fizyczny, psychiczny lub umysłowy trwale lub okresowo utrudnia, ogranicza bądź uniemożliwia wypełnianie ról społecznych, a w szczególności ogranicza zdolności do wykonywania pracy zawodowej.

8 Przepisy te wprowadzono ustawą z dnia 27 maja 2011 roku o zmianie ustawy Kodeks wyborczy oraz ustawy Przepisy wprowadzajace ustawe kodeks wyborczy (Dz. U. 2011, Nr 147, poz. 881), dostosowującej organizację wyborów do potrzeb osób z niepełnosprawnością.

9 http://arboblog.pl/idziemy-na-wybory-wyborcy-niepelnosprawni-rowniez/\#more-8644 (dostęp 23.11.2012). 
Z danych Głównego Urzędy Statystycznego (GUS), ustalonych na podstawie Badania Aktywności Ekonomicznej Ludności (BAEL) przeprowadzonego w 2010 roku dotyczących liczby osób niepełnosprawnych wynika, że prawne orzeczenie o niepełnosprawności posiada 3 miliony 398 tysięcy osób w wieku 15 i więcej lat, co stanowi aż 10,7\% ludności Polski. Do najpopularniejszych przyczyn niepełnosprawności należą schorzenia układu krążenia, narządu ruchu jak również dysfunkcje neurologiczne, dalej wymienić można uszkodzenia narządu wzroku i słuchu. $\mathrm{Na}$ tle populacji, osoby niepełnosprawne są gorzej wyedukowane, jednak zauważalny jest stopniowy wzrost liczby osób wykształconych. W 2010 roku odnotowano 33,7\% niepełnosprawnych z co najmniej średnim i $6,6 \%$ z wyższym poziomem wykształcenia. Udział pracujących, wśród osób niepełnosprawnych osiagnął w roku 2010 wartość 21,9\%. Natomiast stopa bezrobocia osób $\mathrm{w}$ wieku produkcyjnym wyniosła $15,3 \%{ }^{10}$.

Przez wieki stosunek do osób niepełnosprawnych ze strony instytucji państwa oraz społeczeństwa można określić jako negatywny, w najlepszym przypadku obojętny. Zmienił się diametralnie dopiero w XX wieku, czego przykładem jest Polska, gdzie problem niepełnosprawności został zauważony zasadniczo dopiero po roku 1989, kiedy temat osób niepełnosprawnych zagościł w debacie publicznej i co równie istotne, przestał być tzw. „tematem tabu” w mediach ogólnopolskich. Można powiedzieć, że stosunek do osób z dysfunkcją narządu ruchu bądź neurologiczną na przestrzeni poszczególnych wieków bardzo ewoluował, zanim niepełnosprawność została uznana za ważny problem współczesnych społeczeństw, a dbałość o osoby niepełnosprawne stała się niejako obowiązkiem wszystkich rozwiniętych państw, w szczególności zaliczanych bądź zaliczających się do grona liberalnych demokracji. Warto prześledzić pokrótce podejście do osób niepełnosprawnych, gdyż dopiero to pozwoli na ukazanie jak wiele się $\mathrm{w}$ tej materii zmieniło na przestrzeni ostatnich lat.

Dzięki neandertalczykom, którzy grzebali swoich zmarłych, trafiono na pierwsze ślady osób niepełnosprawnych. Jak się okazuje, osoby o zniekształconej budowie ciała również były chowane, choć po ilości biżuterii stwierdzić można, że uznawani byli za osoby mniej cenione w społeczeństwie $^{11}$. Jedną z przyczyn niepełnosprawności było przyjęcie wyprosto-

10 http://www.niepelnosprawni.gov.pl/niepelnosprawnosc-w-liczbach/ (dostęp 23.11.2012).

11 Informacje zaczerpnięte z wykładów Tomasza Sahaja z przedmiotu „Socjologia w rehabilitacji: od czasów prehistorycznych do współczesności”, AWF, 2004. 
wanej postawy ciała, co zmniejszyło o $60 \%$ ekspozycję na światło, stąd niedobory witaminy D i rozwijające się krzywice wśród ludności pierwotnej homo erectus ${ }^{12}$.

W Sparcie na piedestał wznoszono kulturę fizyczną, zapominając przy tym nieomal o rozwoju umysłowym. O losie zdeformowanych noworodków rozstrzygali urzędnicy państwowi, których decyzją porzucane one były na wzgórzach Tajgetu. Reszta słabszych jednostek ginęła $\mathrm{z}$ powodu wycieńczenia $\mathrm{w}$ trakcie procesu wychowania wojenno-sportowego $^{13}$. Nieprzypadkowo to w starożytnej Grecji pojawił się ideał kalokagatii (wysportowany i wykształcony), tak więc upośledzone fizycznie niemowlęta porzucane były na pewną śmierć, a z osób niepełnosprawnych składano ofiary, w celu odkupienia grzechów całej społeczności, co legitymizowały ówczesne rozwiązania prawne. Akceptowa była wyłącznie niepełnosprawność poniesiona w wyniku walki. W tym przypadku weteranami opiekowano się na koszt państwa ${ }^{14}$.

W Imperium Rzymskim, choć rozwiniętym na innych podstawach kulturowych, wysoka sprawność fizyczna była również wartością najbardziej pożądaną, szczególnie wśród żołnierzy, niewolników i gladiatorów. Prawo rzymskie, z jednej strony było bardzo surowe dla osób, które krzywdziły swoje rodziny, z drugiej jednak nakazywało porzucania (eliminacji) zdeformowanych noworodków w ciagu pierwszego tygodnia od urodzenia, gdyż przed wprowadzeniem do rodziny, dziecko nie miało osobowości prawnej ${ }^{15}$.

Chrześcijaństwo wprowadziło nowy kanon zachowań. Życie ludzkie, do którego wszyscy mieli jednakowe prawo, uznano za najwartościowsze i wymagające wszelkiej troski. Chroniono je poprzez zakaz aborcji i porzucania noworodków. Warto zwrócić uwagę, że niebo było bardzo atrakcyjne zwłaszcza dla osób niepełnosprawnych, gdzie przepustką nie było piękne ciało, a dobre życie. Jednak wprowadzono zakaz popełniania samobójstw, jako szybszej drogi dostania się do lepszego świata, jak

12 Ibidem.

13 T. Sahaj, Problem niepetnosprawności w starożytnej kulturze greckiej. Rozważania filozoficzno-społeczne, „Roczniki Naukowe AWF”, Poznań 2003, z. 52, s. $127 \mathrm{i} \mathrm{n.}$

14 Ibidem.

15 E. Żak, Elementy sakralne i karne w uregulowaniach prawa rzymskiego dotyczacych porzucania dziecka, w: Religia i prawo karne w starożytnym Rzymie, pod red. A. Dębińskiego, M. Kuryłowicza, Lublin 1998, s. 89-93. 
również obowiązek pomocy osobom upośledzonym psychicznie i fizycznie $^{16}$.

W Średniowieczu, z powodu biedy, zacofania i wojen przybywało ludzi niepełnoprawnych. Ciało kaleki było źródłem grzechu, ale liczyła się czysta dusza, stąd masowe samobójstwa. Kościół katolicki zapewniał, że zmartwychwstanie gwarantuje budowę somatyczną, taką jaką człowiek osiaga w najlepszym okresie ontogenezy, czyli około 30 roku życia. Twierdzono, że amputowani wstaną cali, a zdeformowani w idealnych proporcjach anatomicznych ${ }^{17}$.

W Renesansie, mimo gwałtownego rozwoju nauki i medycyny, a także powrotu do antycznego ideału pięknego ciała, zaczęły pojawiać się obrazy, na których malarze umieszczali osoby z wyraźnymi cechami zespołu Downa. Wierzono, że osoby niepełnosprawne umysłowo, moga mieć nadprzyrodzone zdolności, pozwalające integrować życie na ziemi ze światem boskim ${ }^{18}$. W XVII-wiecznych utopiach, znaleźć można informacje o sposobach traktowania osób niepełnosprawnych przez społeczeństwo - zalecano eutanazję osób „nieprzydatnych społeczeństwu”19. Równocześnie w XVII-wiecznej Anglii z inicjatywy Wincentego z Paolo powstał pierwszy na świecie zakład dla dzieci upośledzonych, których opieką zajmowały się kobiety stowarzyszone w Ladies of Charity ${ }^{20}$.

Dopiero w XVIII wieku zwrócono szczególną uwagę na sytuację osób biednych i niepełnosprawnych, zaczęły powstawać zakłady opieki dla ludzi najbardziej potrzebujących wsparcia. Wprowadzono emerytury, wypłacane przez państwo, głównie dla żołnierzy, wśród których najwięcej było inwalidów ${ }^{21}$. Znaczenie miała też uchwalona w 1789 roku Deklaracja Praw Człowieka i Obywatela, która w art. I stwierdzała, że „ludzie rodzą się i pozostają wolni i równi w swych prawach”22.

16 Informacje zaczerpnięte z wykładów Tomasza Sahaja z przedmiotu „Socjologia w rehabilitacji...”, op. cit.

17 Ibidem.

18 A. Pospiszl, Dawno, dawno temu..., http://www.anula.pl/dawno-dawno-temu.html (dostęp 23.11.2012).

19 T. More, Utopia, przeł. K. Abgarowicz, Warszawa 1954, s. 152.

20 G. Cywińska-Wasilewska, Podstawowe problemy rehabilitacji i etyka, AWF, Poznań 2004, s. 24.

21 J.-P. Bois, Historia starości. Od Montaigne'a do pierwszych emerytur, przeł. K. Marczewska, Warszawa 1996, s. 180.

22 http://libr.sejm.gov.pl/tek01/txt/konst/francja-18.html (dostęp 23.11.2012). 
Romantyzm natomiast co do zasady nie akceptował niepełnosprawności ruchowej, ceniąc wysoko sprawność fizyczną. Warto przypomnieć, że w 1896 roku wskrzeszono Igrzyska Olimpijskie. W tym samym czasie, w 1892 roku powstał zakład gimnastyki szwedzkiej ${ }^{23}$ w Warszawie ${ }^{24}$. Natomiast tuż po odzyskaniu przez Polskę niepodległości w 1922 roku założono pierwszy klub sportowy dla osób głuchoniemych i ociemniałych w Polsce ${ }^{25}$.

W Niemczech hitlerowskich osoby z dysfunkcjami narządu ruchu czy schorzeniami neurologicznymi uznawano za niegodne życia, bez względu na ich narodowość. Warto również pamiętać, że na przykład Amerykanie w latach 60-tych ludzi niepełnosprawnych umysłowo poddawali sterylizacji. Do wzrostu liczby osób niepełnosprawnych przyczyniły się największe konflikty zbrojne. Zarówno po I jak i II wojnie światowej w zastraszającym tempie przybywało żołnierzy z dysfunkcją narządu ruchu, a także niewidomych po atakach gazami bojowymi ${ }^{26}$. W Polsce przełomowym okazał się rok 1948 kiedy to, Wiktor Dega otworzył oddział rehabilitacyjny przy Klinice Ortopedycznej Akademii Medycznej w Poznaniu ${ }^{27}$.

Jednak tak naprawdę dopiero człowiek współczesny żyjący w czasach gwałtownego rozwoju przemysłu i cywilizacji, a także postępu techniki i medycyny w pełni dostrzegł i zaczął respektować potrzeby osób niepełnosprawnych. W Polsce zainteresowanie niepełnosprawnością pojawiło się co prawda w latach siedemdziesiątych XX wieku, jednakże jeszcze blisko 20 lat było potrzebnych, żeby doszło do pierwszych zmian w świadomości Polaków na ten temat. Mimo to wciąż zauważalne są stereotypy tworzące barierę $\mathrm{w}$ relacjach $\mathrm{z}$ osobami niepełnosprawnymi. Aktualnie istnieją dwa sposoby walki z niepełnosprawnością: profilaktyka zdrowotna i kompleksowa rehabilitacja. W celu zapobiegania niepełnosprawności, dzięki postępowi medycyny możliwe są nie tylko badania, ale i operacje prenatalne. W sytuacji stwierdzenia bardzo ciężkiej wady wrodzonej płodu, dopuszczalna jest aborcja. Dzięki no-

23 System wszechstronnych ćwiczeń zapewniających ogólny rozwój fizyczny.

24 G. Cywińska-Wasilewska, op. cit., s. 25.

25 A. Zembaty, Sport ludzi niepetnosprawnych - jedna z wielu straconych szans polskiej rehabilitacji leczniczej, „Postępy rehabilitacji” 1992, nr 3, s. 53.

26 Informacje zaczerpnięte z wykładów Tomasza Sahaja z przedmiotu ,Socjologia w rehabilitacji...”, op. cit.

27 G. Cywińska-Wasilewska, op. cit., s. 24. 
woczesnym operacjom i metodom rehabilitacji wielu ludzi niepełnosprawnych może normalnie funkcjonować.

Dzięki zaawansowanym technicznie protezom, osoby niepełnosprawne są niemalże w stanie konkurować w zawodach rozgrywanych na światowym poziomie z osobami pełnosprawnymi. Najlepszym przykładem jest Oscar Pistorius, w przypadku którego, naukowcy po przeprowadzeniu licznych badań biomechanicznych stwierdzili, że protezy, z których korzysta lekkoatleta, dają mu przewagę nad pełnosprawnymi biegaczami, dzięki wyeliminowaniu narastającego zmęczenia mięśni kończyn dolnych. Osoby mające problemy z poruszaniem się, dzięki wózkom inwalidzkim coraz nowszej technologii mogą swobodnie się przemieszczać. W zależności od indywidualnych potrzeb osób z dysfunkcją fizyczną, produkowane są wózki o ażurowych konstrukcjach, albo z napędem elektrycznym. Wyróżnić można także liczne modele wózków specjalnie przystosowanych do uprawiania różnych dyscyplin sportowych, dzięki czemu osoby niepełnosprawne mogą grać w koszykówkę, tenisa czy rugby. Wózki, projektowane na zamówienie, uwzględniające indywidualne potrzeby jednostki, pozwoliły normalnie funkcjonować takiemu geniuszowi, jakim jest Stephen William Hawking, którego wózek wyposażony jest w komputer ze specjalną klawiaturą i syntetyzator mowy, dzięki czemu, w znacznym stopniu sparaliżowany brytyjski astrofizyk, kosmolog i fizyk teoretyk, cierpiący na stwardnienie zanikowe boczne, może z powodzeniem wypełniać poszczególne role społeczne. Mimo znacznego paraliżu jest członkiem Royal Society i honorowym członkiem Royal Society of Arts, a także dożywotnim członkiem Papieskiej Akademii Nauk. Odznaczony został Orderem Imperium Brytyjskiego i Medalem Wolności, najwyższym odznaczeniem cywilnym USA. Jego niesamowite odkrycia i wydawane książki o tematyce kosmologicznej uczyniły z niego akademickiej sławy naukowca.

W trosce o potrzeby osób niepełnosprawnych projektowane są inteligentne domy, które uwzględniają wszelkie potrzeby i możliwości osób poruszających się na wózkach. Poszczególne pomieszczania są tak umeblowane, żeby osoba nie miała problemów z przemieszczaniem się. Montowane są ruchome szafy, a pozostałe sprzęty instalowane są w zasięgu ręki osoby siedzącej na wózku, dzięki czemu niepełnosprawni mogą być samodzielni. Domy dla bezpieczeństwa wyposażyć można w czujniki dymu, gazu czy wody, a dzięki zastosowaniu automatyki za pomocą jednego przycisku można wyłączyć światło i wszystkie sprzęty AGD i RTV, jak również opuścić rolety i załączyć alarm. 
Architekci zajmujący się planowaniem infrastruktury i zagospodarowaniem przestrzeni, z myślą o osobach niepełnosprawnych, projektują podjazdy i windy, które są już standardem w nowoczesnym świecie zorientowanym na potrzeby osób niepełnosprawnych. Dzięki temu jednostki poruszające się na wózkach bez większych problemów mogą dostać się do urzędów, banków, szkół, kin czy pływalni. Bankomaty instalowane są na niewielkiej wysokości, aby osoby te mogły być niezależne. Co więcej, Muzeum Narodowe w Poznaniu ze względu na wprowadzenie najnowszych rozwiązań otrzymało tytuł Miejsca Przyjaznego Osobom Niepełnosprawnym. Ponadto, otwierane są biblioteki dla niewidomych i niedowidzących z książkami pisanymi Braillem czy nagranymi na płytach CD do odsłuchania ${ }^{28}$.

Osoby niepełnosprawne nie mają większych problemów - albo raczej nie powinny ich mieć - z przemieszczaniem się. Produkowane są samochody fabrycznie dostosowane do możliwości ludzi z dysfunkcjami narządu ruchu, przed urzędami, galeriami, pływalniami wyznaczane są specjalne miejsca parkingowe, a w budynkach toalety odpowiednio dostosowane do potrzeb osób niepełnosprawnych. Komunikacja miejska w głównej mierze złożona jest $\mathrm{z}$ niskopodłogowych autobusów i tramwajów. Przejścia dla pieszych z niskimi krawężnikami i wszechobecnymi przyciskami umożliwiającymi niemal natychmiastowe przejście przez ulicę, oczywiście zainstalowanymi na wysokości rąk osoby siedzącej na wózku, ułatwiają poruszanie się paraplegikom. Natomiast przejścia wyposażone w wypustki dla niewidomych czy emitowany sygnał dźwiękowy pozwalają na bezpieczne i samodzielne wyprawy osób niewidomych ${ }^{29}$.

Internet otworzył okno na świat osobom niepełnosprawnym, którym pozwolił na łatwy kontakt z innymi ludźmi w podobnej sytuacji. Przez Internet wielu niepełnosprawnych znalazło sobie partnera życiowego. Wirtualne uczelnie wyższe pozwalają na zdobycie wykształcenia bez wychodzenia z domu. Sporym zainteresowaniem wśród osób niepełnosprawnych cieszy się nie tylko teleedukacja czy e-learning, ale również telepraca, dzięki której jednostki mogą być aktywne zawodowo i czynnie uczestniczyć w życiu państwa. Przez Internet można dokonywać transakcji bankowych, robić zakupy, czy kontaktować się z lekarzem prowadzącym ${ }^{30}$.

28 Informacje zaczerpnięte z wykładów Tomasza Sahaja z przedmiotu „Socjologia w rehabilitacji...", op. cit.

29 Ibidem.

30 Ibidem. 
Najnowszej generacji telefony komórkowe, pozwalają na głosowe wybieranie połączeń, co więcej dostępne są systemy przetwarzające ręcznie pisane teksy na monitorze na drukowane. Również osiągnęliśmy taki poziom techniki, że wiadomości tekstowe zamieniane są na głosowe i odczytywane przez lektora. Można również nagrać swoją odpowiedź, która zostanie wysłana w formie sms'a lub wiadomości głosowej. Ekrany telefonów komórkowych są bardzo duże, co ułatwia ich obsługę osobom niedowidzącym ${ }^{31}$.

Rewolucyjnej zmiany dokonało powstanie języka migowego, który umożliwia porozumiewanie się z osobami głuchoniemymi, jak wiele innych sposobów komunikacji z osobami niebędącymi w stanie porozumiewać się w sposób werbalny. Przykładem może być Jean-Dominique’a Bauby, francuski dziennikarz, redaktor czasopisma ELLE, który w wyniku przebytego udaru, został kompletnie sparaliżowany, z wyjątkiem lewego oka. Zdołał w tym stanie napisać książkę Skafander i motyl. Pomogła mu w tym przedsięwzięciu osoba recytująca specjalny alfabet, w którym litery występują w kolejności najczęściej używanych, a on mrugał okiem, kiedy została wypowiedziana żądana litera. Nowoczesna technika poradziła sobie również z porozumiewaniem się z osobami całkowicie sparaliżowanymi, wystarczy, że opanują sztukę podświetlania liter na wyświetlaczu, wykorzystując energię bioelektryczną mózgu ${ }^{32}$.

Z myślą o osobach upośledzonych fizycznie bądź umysłowo powstają na terenie państwa Polskiego liczne organizacje i instytucje działające na rzecz niepełnosprawnych. Zrzeszają one osoby z dysfunkcjami i pomagają im odnaleźć się w zaistniałej sytuacji poprzez rehabilitację zawodową i społeczną. Do najważniejszych należy Państwowy Fundusz Rehabilitacji Osób Niepełnosprawnych (PFRON) działający na mocy ustawy z dnia 27 sierpnia 1997 roku o rehabilitacji zawodowej i społecznej oraz zatrudnianiu osób niepełnosprawnych, będący jednostką administracji funkcjonującą na rzecz rehabilitacji i zatrudnienia osób niepełnosprawnych. Pieniądze przeznaczane są na likwidację różnego rodzaju barier m.in. architektonicznych i środowiskowych, tworzenie miejsc pracy dla osób upośledzonych czy organizację Warsztatów Terapii Zajęciowej, będących strukturą regulowaną ustawą z dnia 9 maja

31 Ibidem.

32 Ibidem. 
1991 roku $^{33}$, a częściowo finansowaną przez PFRON. Celem, około 300 istniejących takich placówek, jest rehabilitacja przez sztukę osób niepełnosprawnych powyżej 16-stego roku życia. Niezależnie, na terenie kraju istnieje około 4,5 tysiąca instytucji pozarządowych zrzeszających osoby niepełnosprawne na terenie III RP. Funkcjonują organizacje takie jak Stowarzyszenie Przyjaciół Integracji, celem którego jest działalność informacyjna oraz Fundacja Polska bez Barier, do której zadań należy aktywizacja społeczno-zawodowa osób niepełnosprawnych.

W 2011 roku Sportowe Stowarzyszenie Inwalidów Start w Poznaniu obchodziło jubileusz 50-lecia polskiego sportu niepełnosprawnych. Natomiast blisko dwadzieścia pięć lat temu na terenie Polski zaczęła funkcjonować Fundacja Aktywnej Rehabilitacji, integrująca głównie osoby po wypadkach, w wyniku których doszło do urazu rdzenia kręgowego, a jednostka funkcjonuje poruszając się na wózku inwalidzkim ${ }^{34}$.

W 1998 roku powstał Polski Komitet Paraolimpijski, do zadań którego należy działalność na rzecz rozwoju sportu osób niepełnosprawnych. Wśród Igrzysk Letnich wymienić należy takie dyscypliny jak: łucznictwo, lekkoatletyka, kolarstwo, jeździectwo, judo, wioślarstwo, żeglarstwo, pływanie, tenis stołowy, siatkówka oraz koszykówka, taniec, szermierka, rugby i tenis na wózkach. W czasie Igrzysk Zimowych natomiast rozgrywane są następujące konkurencje: biathlon, hokej na siedząco, narciarstwo biegowe, narciarstwo alpejskie i curling na wózkach ${ }^{35}$.

W 2005 roku Polskie Stowarzyszenie Osób Niepełnosprawnych (PSON) działające na rzecz osób niepełnosprawnych, w tym organizujące obozy konne, żeglarskie i narciarskie, uzyskało status organizacji pożytku publicznego. Wśród innych instytucji, oprócz tych zrzeszających osoby z podobną jednostką niepełnosprawności jak: Polski Związek Niewidomych, Polski związek Głuchych, Polskie Towarzystwo Stwardnienia Rosianego, wymienić należy Stowarzyszenie Jeździeckie Osób Niepełnosprawnych Hippoland, Stowarzyszenie Kultury Fizycznej, Sportu i Turystyki Niewidomych i Słabowidzących Cross, Polski Związek Żeglarzy Niepełnosprawnych, Polski Związek Tenisa na Wózkach, Grupę Taneczną Twister (taniec na wózkach) czy Kibice na wózkach.

33 Warsztaty terapii zajęciowej zostały powołane na mocy ustawy z dnia 9 maja 1991 r. o zatrudnieniu i rehabilitacji osób niepetnosprawnych, Dz. U. 1991, Nr 38, poz. 166 ze zm.

34 Por. http://start.org.pl, http://www.far.org.pl (dostęp 23.11.2012).

$35 \mathrm{http} / / /$ www.paralympic.org.pl/ (dostęp 23.11.2012). 
Z pewnością wpływ na zwrócenie większej uwagi na potrzeby osób niepełnosprawnych mają niepełnosprawni parlamentarzyści. Pierwszym i najbardziej znanym jest Jan Filip Libicki, z wykształcenia historyk, który w latach 1998-2002 był członkiem zarządu Polskiego Komitetu Paraolimpijskiego, a od 1999 do 2002 dzierżył stanowisko doradcy prezesa Państwowego Funduszu Rehabilitacji Osób Niepełnosprawnych. Kolejnym jest Poseł RP Marek Plura, który ze względu na postępujący zanik mięśni jeździ na wózku elektrycznym. Jest pedagogiem i psychoterapeuta, pomimo niepełnosprawności utrzymuje żonę i dwoje dzieci. Następnym posłem poruszającym się na wózku jest Sławomir Piechota, z wykształcenia prawnik. Był pełnomocnikiem wojewody wrocławskiego ds. osób niepełnosprawnych, przewodniczącym wrocławskiej Rady Miejskiej, wiceprezydentem Wrocławia ${ }^{36}$.

Jednak głębsza analiza polskich realiów nasuwa wniosek, że cały czas wszystko to brzmi trochę jak XVII-wieczna utopia. W Polsce praktycznie problemu niepełnosprawności nie widać, ponieważ osoby te pozostają w domach lub przebywają w szpitalach. Mimo wszystkich wyżej wymienionych udogodnień, niepełnosprawni nie uczestniczą w życiu społecznym i politycznym III RP. Fakt ten nie wynika tyle ze złej woli władz, co raczej ze zbyt małej świadomości potrzeb osób niepełnosprawnych. Zupełnie inną kwestią są również koszty i dostęp do nowinek technicznych.

Życie ludzkie bardzo się wydłużyło w ostatnich dziesięcioleciach, niestety to tylko ta bardziej błyszcząca strona medalu, drugą jest jakość życia, która już pozostawia sporo do życzenia. Kiedyś większy odsetek ludzi umierał, teraz podtrzymywani przy życiu osiagają sędziwy wiek, niestety w zupełności zdani na innych. Wprowadzenie zakazu przerwania ciąży, niewątpliwie podkreśla ważność każdego istnienia. Prowadzi jednak do gwałtownego rozwoju turystyki aborcyjnej i skazuje niektóre jednostki na całe życie leżenia pod respiratorem. Są wspaniałe protezy dla ludzi po różnego rodzaju amputacjach, ale poza zasięgiem budżetowym osób niepełnosprawnych. Również o wózkach z „najwyższej półki” większość może również śmiało zapomnieć. Prawdopodobnie o istnieniu ruchomych domów zdecydowana większość nawet nie słyszała. Mieszkając w kamienicach czy blokach bez wind, nawet nie mają

36 http://www.mnd.pl/forum/index.php/topic, 1738.0.html (dostęp 23.11.2012). 
możliwości opuszczenia mieszkania bez pomocy przynajmniej czterech osób, które zniosłyby wózek ${ }^{37}$.

Niestety problemy osób niepełnosprawnych nigdy nie będą ani łatwe do rozwiązania, ani tanie. Przykładem mogą być niskie krawężniki, które będąc rewelacyjnym rozwiązaniem dla ludzi przemieszczających się na wózkach, są zmorą osób niewidomych, którym trudno ustalić czy wciąż są na chodniku, czy może już na jezdni. Język migowy to świetna idea, ale tylko garstka pełnosprawnych osób potrafi się w nim porozumiewać. Igrzyska olimpijskie dla osób z dysfunkcją narządu ruchu są fenomenalnym pomysłem, ale tylko nieliczni niepełnosprawni mogą sobie pozwolić na kilka treningów w tygodniu, reszta ma problem z samodzielnym dotarciem na zajęcia. Narciarstwo, tenis, żeglarstwo to wspaniałe dyscypliny sportu, niestety w znakomitej większości poza zasięgiem finansowym osób niepełnosprawnych. Co więcej, nauczanie indywidualne, teleedukacja czy teleprace są fantastycznym rozwiązaniem, ale wykluczają niepełnosprawne jednostki i mimo, iż uczestniczą w życiu społecznym, pozostają w odosobnieniu.

Przyjmuje się, że około 10\% światowej populacji stanowi ludność dotknięta niepełnosprawnościa, dotyczy to zarówno społeczeństw bardziej technicznie zaawansowanych, jak i tych mniej rozwiniętych. Wbrew pozorom problem wydaje się większy w krajach bogatszych o znacznie wyższym poziomie życia, gdzie wraz z rozwojem medycyny, zmniejszony został odsetek śmiertelności, a życie człowieka zostało wydłużone. Niepełnosprawność, to nie tylko ograniczenia funkcjonalne jednostki wynikające ze schorzenia, ale i bariery architektoniczne, komunikacyjne, organizacyjne i środowiskowe, które stawia przed osobami niepełnosprawnymi świat „normalnych” ludzi. Nie ulega wątpliwości, że osoby upośledzone ruchowo bądź umysłowo są mniej wykształcone i aktywne zawodowo, a co za tym idzie, ich sytuacja materialna, jest bardzo trudna. Dla przykładu na 700 osób zatrudnionych w Ministerstwie Obrony Narodowej zaledwie 6 stanowią osoby niepełnosprawne ${ }^{38}$. Z roku na rok wzrasta liczba osób niepełnosprawnych zarejestrowanych w urzędach pracy, jak również tych zatrudnionych $\mathrm{w}$ zakładach pracy chronionej.

37 Warto się przyjrzeć na przykład wejściu do poznańskiego Ratusza, zdobiącego poznański Stary Rynek, przecież to istna twierdza nie do zdobycia dla paraplegika.

38 T. Tomaszewski, Trudna sytuacja osób niepetnosprawnych, http://bielany-sld.pl/sld/388-tomaszewski-trudna-sytuacja-osob-niepenosprawnych-08022011 (dostęp 23.11.2012). 
Równocześnie przy mniejszych zarobkach, rencie czy skromniejszej emeryturze w porównaniu z wysokością świadczeń przysługujących osobom pełnosprawnym, niepełnosprawni wydają na opiekę medyczną trzykrotnie więcej niż osoby zdrowe. Natomiast gorszy dostęp do dóbr i usług umożliwiających pełne życie społeczne, oznacza, że jednostki te wciąż funkcjonują na uboczu populacji. Problemy osób z różnego rodzaju dysfunkcjami, doskonale odzwierciedlają zmiany zachodzące w polityce społecznej państwa polskiego. „Model socjalistycznego państwa opiekuńczego powoli zastępowany zostaje przez model państwa demokratycznego, opartego na funkcjonowaniu społeczeństwa obywatelskiego, w którym obywatele biorą aktywny udział w rozwiązywaniu problemów ważnych z ich punktu widzenia. Oczywiście zadaniem aparatu państwowego jest wspieranie organizacji społecznych poprzez zapewnienie im odpowiednich warunków rozwoju w zakresie rozwiązywania problemów niepełnosprawności (subwencji, grantów, dotacji, programów celowych)"39.

W Polsce osoby niepełnosprawne teoretycznie mają możliwość brania czynnego udziału w procesie budowania liberalno-demokratycznej III RP, jako pełnoprawni obywatele - wyborcy, ale tylko nieliczne jednostki wywiązują się ze swoich ról społecznych i obowiązków wobec państwa. Warto przypomnieć, że w 1997 roku uchwałą Sejmu, przyjęto Kartę Praw Osób Niepełnosprawnych, która określa prawa osób niepełnosprawnych, wymieniając między innymi prawo dostępu do urzędów, punktów wyborczych i obiektów użyteczności publicznej, swobodnego przemieszczania się i powszechnego korzystania ze środków transportu, dostępu do informacji, możliwości komunikacji międzyludzkiej ${ }^{40}$.

Należy mieć nadzieję, że rozwiązania zawarte i wprowadzone w życie w kodeksie wyborczym, innych aktach prawnych i dokumentach oraz coraz liczniejsze kampanie społeczne, mające na celu wyborczą aktywizację osób niepełnosprawnych, wpłyną pozytywnie na ten proces. Sytuacja społeczno-polityczna osób niepełnosprawnych w Polsce systematycznie się poprawia, nadal jednak jest na tym polu bardzo wiele do zrobienia.

39 Centrum Badań i Rozwoju Kształcenia, Raport o sytuacji osób niepełnosprawnych $w$ Polsce, http://www.cbe.ahe.lodz.pl/archiwalna_cbrk/sytuacja\%20osob.pdf (dostęp 23.11.2012).

40 Ibidem. 
The socio-political status of the disabled in modern Poland

\begin{abstract}
Summary
The paper discusses and illustrates the most significant issues related to the functioning of the disabled in the social and political dimensions. The evolution of social attitudes to people with disabilities over the centuries is shown. The paper discusses the matters of how Poles perceive disability, the solutions in the electoral code and other legal acts and documents, and increasingly frequent social awareness campaigns that are aimed to encourage the disabled to vote in elections, which all have a beneficial impact on the process of activization of the disabled as rightful citizens. The paper is interdisciplinary, encompassing the points of view of a researcher dealing with physiotherapy and that of a researcher into political science, making it unique.
\end{abstract}

